\title{
The Influencing Factors of Liability Management of New Energy Listed Companies in China
}

\author{
Xu Min ,Yang Lihong \\ College of Management, Xi'an University of Science and Technology \\ No.58, Yanta Road, Beilin District, Xi'an, Shaanxi Province, China
}

\begin{abstract}
The vigorous development of new energy industry plays an important role in promoting the sustainable development of China's economy. The effectiveness of debt management of new energy companies in China plays a decisive role in the healthy and stable development of new energy industry. Based on the annual data and the main financial indicators of China's new energy listed companies, this paper used the factor analysis method, the correlation analysis method and the linear regression model to analyzed the new energy market of China found the impact of the company's debt management factors. The results show that the profitability and scale of enterprises are positively related to debt management. Finally, on the basis of the present situation and the empirical analysis, the countermeasures and suggestions are put forward to optimize the enterprise debt management.
\end{abstract}

Keywords-new energy listed companies; debt management; influencing factors

\section{INTRODUCTION}

In recent years, China's social production technology continues to increase, energy consumption has increased significantly, the traditional non-renewable energy (such as coal, oil, natural gas, etc.) increasingly reduced, has been unable to meet the current development needs [1]. At the same time, emerging clean energy (such as combustible ice, biomass, etc.) will be born, it is an important area to solve future energy problems and environmental issues. At present, China has promulgated a lot of laws and regulations in clear the optimization of energy goals and direction, and paying more attention to the development and utilization of new energy [2]. For China's new energy industry enterprises, the core issue of expanding the scale of enterprises is to raise funds, and in recent years, China's rapid economic development of the state, enterprises to raise funds channels began to diversify, debt management has been owned by enterprises And managers highly favored.

\section{THE STUDY OF THE PROPOSED HYPOTHESIS}

At present, domestic and foreign scholars have had a lot of empirical research on the factors that affect the operation of new energy liabilities in China. This paper draws some of the research methods to screen out the indicators that may affect the debt management of enterprises, and quantify them in the empirical research part. The assumptions in this paper are as follows [3]:

Hypothesis 1: The profitability of new energy listed companies have a certain impact on their debt management, and is a positive correlation.

Hypothesis 2: The development of new energy listed companies have a certain impact on their debt management, and a positive correlation.

Hypothesis 3: The operational capacity of new energy companies has a certain impact on their debt management, and is a positive correlation.

Hypothesis 4: The size of the new energy companies have a certain impact on their debt management, and is a positive correlation.

\section{THE CHOICE OF VARIABLES AND MODEL CONSTRUCTION}

\section{A. The choice of variables}

\section{1) Dependent Variable}

The security of investment funds is the most concern of each creditor, so they must pay more attention to the other company's solvency in the investment. And the asset-liability ratio of listed companies is also an important indicator of its solvency [4]. In general, the firm's own capital is very stable and is not easy to change. Therefore, it is regarded as the explanatory variable Y (asset-liability ratio = total liabilities / total assets).

\section{2) Independent Variable}

Through the summary of the previous research results, we found that the emerging industry enterprises profitability, development capacity, operational capacity and the size of the company can also be used as an explanatory variable. Using factor analysis method to reduce the dimension extraction, and then through the correlation analysis and regression analysis to test, come to the final conclusion [5]. From the company's own point of view of the factors selected, the main situation in the following table: 
TABLE I. SELECTION OF INDEPENDENT VARIABLES

\begin{tabular}{|c|c|c|}
\hline Factor Type & Argument Name & Variable Definition \\
\hline Profitability $\left(\mathrm{X}_{1}\right)$ & $\begin{array}{l}\text { Return on net assets } \\
\text { Total net profit margin } \\
\text { Operating net profit }\end{array}$ & $\begin{array}{c}\text { Net profit / net assets } \\
\text { Total profit / total assets } \\
\text { Operating profit / operating income }\end{array}$ \\
\hline $\begin{array}{l}\text { Development } \\
\text { Capacity }\left(\mathrm{X}_{2}\right)\end{array}$ & $\begin{array}{l}\text { Total Asset Growth Rate } \\
\text { Operating income growth rate } \\
\text { Net profit growth }\end{array}$ & $\begin{array}{l}\text { rate of assets this year / total assets of the previous year } \\
\text { Revenue from operating income / operating income for the previous year } \\
\text { Net profit growth / net profit for the previous year }\end{array}$ \\
\hline $\begin{array}{l}\text { Operational } \\
\text { Capacity }\left(\mathrm{X}_{3}\right)\end{array}$ & $\begin{array}{l}\text { Total asset turnover } \\
\text { Accounts receivable turnover } \\
\text { Current Assets Turnover }\end{array}$ & $\begin{array}{l}\text { Operating income / total assets } \\
\text { Operating income / average balance of accounts receivable } \\
\text { Net income from main operations / total current assets }\end{array}$ \\
\hline Enterprise Size $\left(\mathrm{X}_{4}\right)$ & $\begin{array}{c}\text { Total Assets Natural Number } \\
\text { Logarithm }\end{array}$ & LN (Total Assets) \\
\hline
\end{tabular}

\section{B. The Construction of the Model}

The main financial indicators of the business as a variable for the relevant analysis, the following structural regression equation:

$$
\mathrm{Y}=\mathrm{a}+\mathrm{b}_{1} \mathrm{X}_{1}+\mathrm{b}_{2} \mathrm{X}_{2}+\mathrm{b}_{3} \mathrm{X}_{3}+\mathrm{b}_{4} \mathrm{X}_{4}+\mathrm{u}
$$

In the above formula, $\mathrm{Y}$ represents the asset-liability ratio, $\mathrm{X}_{1}, \mathrm{X}_{2}, \mathrm{X}_{3}, \mathrm{X}_{4}$, represents the profitability, development capacity, operational capacity and business scale, constant a is fixed, $\mathrm{u}$ is the uncertainty constant error, the regression equation parameters estimate.

\section{Sample Selection}

After the removal, we selected the 2012-2016 Shanghai and Shenzhen listed companies, the continuous disclosure of financial reports of 56 new energy companies as a research object, the total sample are 280 .

\section{EMPIRICAL ANALYSIS}

\section{A. Factor Analysis}

In this paper, factor analysis is used to study the internal relations between several explanatory variables, and the variables that can reflect the main information (that is, the explanatory variables) can be fully reflected by many variables. The following is a detailed process for factor analysis of the independent and dependent variables of the model.

\section{1) KMO Test and Bartlett test}

TABLE II. KMO AND BARTLETT

\begin{tabular}{|c|c|c|}
\hline \multicolumn{2}{|c|}{ Kaiser-Meyer-Olkin Measure of Sampling Adequacy } & .513 \\
\hline \multirow[t]{3}{*}{ Bartlett's Test of } & Approx. Chi-Square & 784.911 \\
\hline & $\mathrm{df}$ & 36 \\
\hline & Sig. & .000 \\
\hline
\end{tabular}

According to the mathematical definition of KMO (KaiserMeyer-Olkin), when the value is between 0.5 and 1 , the selected variable applies to factor analysis. The closer to 1 indicates that the method is more suitable for using. Here the value is 0.513 , and the Bartlett spherical tested statistic of this group is 784.911 , the probability of arrival is almost 0 , reaching the significance level, KMO value and Bartlett spherical test combined, so the group of variables apply factor analysis.

\section{2) The Total Variance Decomposition Table}

TABLE III. EXPLANATION OF TOTAL VARIANCE

\begin{tabular}{c|c|c|c|c|c|c|c|c|c}
\hline \multirow{2}{*}{ Component } & \multicolumn{4}{|c|}{ Initial Eigenvalue } & \multicolumn{2}{|c|}{ Extracts Sums the of Squared Loading } & \multicolumn{3}{|c}{ Road Sum of Squared Loadings } \\
\cline { 2 - 9 } & Total & \% of Variance & Cumulative \% & Total & \% of Variance & Cumulative \% & Total & \% of Variance & Cumulative \% \\
\hline \multirow{2}{*}{1} & 2.298 & 22.984 & 22.984 & 2.298 & 22.984 & 22.984 & 2.092 & 20.923 & 20.923 \\
2 & 1.871 & 18.707 & 41.692 & 1.871 & 18.707 & 41.692 & 1.857 & 18.574 & 39.496 \\
3 & 1.539 & 15.386 & 57.077 & 1.539 & 15.386 & 57.077 & 1.738 & 17.379 & 56.875 \\
4 & 1.093 & 10.927 & 68.004 & 1.093 & 10.927 & 68.004 & 1.113 & 11.129 & 68.004 \\
5 & .975 & 9.753 & 77.758 & & & & & & \\
6
\end{tabular}




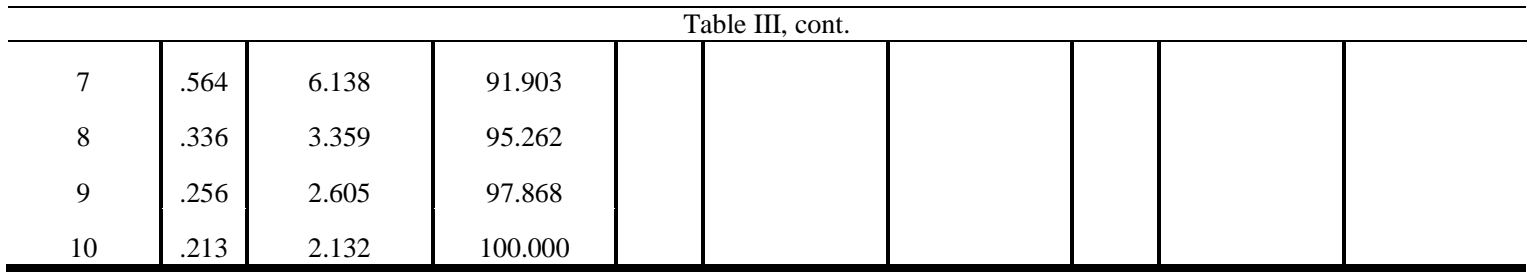

From the results of Table III, it can be concluded that after the extraction, there are four factors of eigenvalues greater than 1 , so these four factors as the initial research factor, the first four factors of rotation on the overall variance of the interpretation of the ratio were $22.984 \%, 18.707 \%, 15.386 \%$, $10.927 \%$, and the accumulated variance contribution rate was $68.004 \%$. The explanatory ratios of the four factors after rotation were $20.923 \%, 18.574 \%, 17.379 \%$ and $11.129 \%$ respectively, and the cumulative explanatory rate was $68.004 \%$. In general, the cumulative explanatory rate of the original variable before and after rotation is the same, indicating that the information loss is less and the analysis result is ideal.

3) After the Rotation of the Factor Load Value Table

TABLE IV. ROTATED COMPONENT MATRIX

\begin{tabular}{ccccc}
\hline & \multicolumn{3}{c}{ Component } \\
\cline { 2 - 5 } & 1 & 2 & 3 & 4 \\
\hline Accounts receivable turnover rate & -.207 & .640 & .153 & .210 \\
Current Assets Turnover & .042 & .862 & -.059 & .040 \\
Total Asset Turnover & .109 & .803 & -.110 & -.311 \\
Total net profit margin & .916 & .082 & .110 & -.017 \\
Return on net assets & .840 & .031 & .030 & .054 \\
Operating net profit margin & .658 & -.124 & .054 & .043 \\
Total asset growth rate & .067 & -.069 & .276 & -.178 \\
Operating income growth rate & .080 & -.118 & .856 &. .630 \\
Net profit growth rate & .101 & .056 & .194 & .121 \\
The total number of natural asset & .190 & -.126 & .723
\end{tabular}

Extraction method: Principal component analysis. Rotation method: Kaiser normalized maximum variance methoda.

From the above table we can see that the correlation between the first factor (profitability $\mathrm{X}_{1}$ ) and the three indexes of "net assets", "net assets yield" and "net operating margin" are strong and positive The correlation between the other factors is weak and the second factor (operating capacity $\mathrm{X}_{2}$ ) is positively correlated with the "current asset turnover rate", "total asset turnover rate" and "accounts receivable turnover a. The rotation has converged after 4 iterations.

rate" The correlation between the third factor (development ability $\mathrm{X}_{3}$ ) and the "total asset growth rate" and "net profit growth rate" are strong, positive, and the correlation with other indicators is weak; the fourth Factor (firm size $\mathrm{X}_{4}$ ) has a strong correlation with its "total asset natural logarithm".

\section{4) Calculate the Coefficient Matrix of the Factor Values}

TABLE V. COMPOSITION SCORE COEFFICIENT MATRIX

\begin{tabular}{|c|c|c|c|c|}
\hline & \multicolumn{4}{|c|}{ Component } \\
\hline & 1 & 2 & 3 & 4 \\
\hline Accounts receivable turnover rate & -.124 & .362 & .137 & .227 \\
\hline Current Assets Turnover & .024 & .467 & -.008 & .069 \\
\hline Total Asset Turnover & .073 & .418 & -.054 & -.254 \\
\hline Total net profit margin & .442 & .046 & -.017 & -.040 \\
\hline Keturn on net assets & .410 & .019 & -.057 & .023 \\
\hline Operatıng net profıt margin & .318 & -.064 & -.032 & .013 \\
\hline Total asset growth rate & -.045 & -.013 & .529 & -.146 \\
\hline Operating income growth rate & .035 & -.081 & .139 & -.571 \\
\hline Net profit growth rate & -.033 & .065 & .508 & .127 \\
\hline The total number of natural asset & .052 & -.032 & .109 & .646 \\
\hline
\end{tabular}

According to Table V, we can get the score function of four factors, no longer enumerated here. Through the score function formulate, we can automatically calculated the company's annual index of 10 indicators of the value. After the 
dimensionality reduction, the specific values of each company of $\mathrm{X}_{1}, \mathrm{X}_{2}, \mathrm{X}_{3}$ and $\mathrm{X}_{4}$ were obtained each year, and the obtained data were collected into correlation analysis and regression analysis.

\section{B. Correlation Analysis}

TABLE VI. CORRELATIONS ANALYSIS OF VARIABLES

\begin{tabular}{|c|c|c|c|c|c|c|c|}
\hline & & $X_{1}$ & $X_{2}$ & $X_{3}$ & $X_{4}$ & $Y$ & \\
\hline \multirow[t]{3}{*}{$\mathrm{X}_{1}$} & Pearson Correlation & 1 & .000 & .000 & .000 & $.272^{* *}$ & \\
\hline & Sig.(2-tailed) & & 1.000 & 1.000 & 1.000 & & .000 \\
\hline & $\mathrm{N}$ & 280 & 280 & 280 & 280 & 280 & \\
\hline \multirow[t]{3}{*}{$\mathrm{X}_{2}$} & Pearson Correlation & .000 & 1 & .000 & .000 & .048 & \\
\hline & Sig.(2-tailed) & 1.000 & & 1.000 & 1.000 & .402 & \\
\hline & $\mathrm{N}$ & 280 & 280 & 280 & 280 & 280 & \\
\hline \multirow[t]{3}{*}{$\mathrm{X}_{3}$} & Pearson Correlation & .000 & .000 & 1 & .000 & .000 & \\
\hline & Sig.(2-tailed) & 1.000 & 1.000 & & 1.000 & .994 & \\
\hline & $\mathrm{N}$ & 280 & 280 & 280 & 280 & 280 & \\
\hline \multirow[t]{3}{*}{$\mathrm{X}_{4}$} & Pearson Correlation & .000 & .000 & .000 & 1 & $.296^{* *}$ & \\
\hline & Sig.(2-tailed) & 1.000 & 1.000 & 1.000 & & .000 & \\
\hline & $\mathrm{N}$ & 280 & 280 & 280 & 280 & 280 & \\
\hline \multirow[t]{3}{*}{$\mathrm{Y}$} & Pearson Correlation & $.272^{* *}$ & .048 & .000 & $.296^{* *}$ & 1 & \\
\hline & Sig.(2-tailed) & .000 & .402 & .994 & .000 & & \\
\hline & $\mathrm{N}$ & 280 & 280 & 280 & 280 & 280 & \\
\hline
\end{tabular}

From Table VI, we can conclude that the explanatory coefficients of the four explanatory variables $\mathrm{X}_{\mathrm{i}}$ and the explanatory variables $\mathrm{Y}$ are $0.272,0.048,0.00,0.296$ respectively, which shows the profitability of the firm $X_{1}$ and the enterprise scale $\mathrm{X}_{4}$ and the enterprise asset-liability ratio $\mathrm{Y}$ There is a significant positive correlation. And then shows that corporate profitability and its size for its debt financing operations have a greater impact. And its operational capacity and development capacity and asset-liability ratio is not obvious, so in the following regression analysis will be excluded $\mathrm{X}_{2}$ and $\mathrm{X}_{3}$.

\section{Regression Analysis}

TABLE VII. MODEL SUMMARY

\begin{tabular}{|c|c|c|c|c|c|c|c|c|c|}
\hline & & & & & \multicolumn{5}{|c|}{ Statistics Changed } \\
Model & $R$ & $R$ Square & Adjusted $R$ & Std.Error of & $R$ Square & & & & Sig. F \\
Square & the Estimate & changed & F changed & $d f 1$ & $d f 2$ & changed \\
\hline 1 & $.402 \mathrm{a}$ & .162 & .156 & .15789 & .162 & 29.646 & 2 & 307 & .000 \\
\hline
\end{tabular}

a. Predictors : (Constant),Profitability (X1), Enterprise Size (X4)

Table VII shows the statistics of the regression equation. Among them, it should be noted that the value of $\mathrm{R}$ should be between 0-1 for the complex correlation coefficient, according to the definition, the value of the closer 1 indicates that the model of the independent variable and the dependent variable between the linear regression relationship. Where the value is
0.402 , indicating that the independent variable and the dependent variable are at a moderate level. The square of $\mathrm{R}$ is 0.162 , indicating that the independent variable can account for $16.2 \%$ of the dependent variable. The significance of the $\mathrm{F}$ value of 0.000 , through the significance of detection. 
TABLE VIII. ANOVA

\begin{tabular}{ccccccc}
\hline \multicolumn{1}{c}{ Sum of } & & & & \\
& Model & Squares & $d f$ & Mean Square & $F$ & Sig. \\
\hline \multirow{2}{*}{1} & Regression & 1.478 & 2 & .739 & 29.646 & $.000^{\mathrm{b}}$ \\
& Residual & 7.653 & 307 & .025 & & \\
& Total & 9.131 & 309 & & & \\
\hline
\end{tabular}

a.Variables: Asset - liability ratio

b. Predicted variables: (constant), profitability (X1), total assets, natural logarithm (X4)

Table VIII shows the results of the variance analysis of the regression model, where the value of the F statistic is 29.646, indicating that the linear relationship between the model variables is obvious. The significance value is 0.000 (less than
0.005), then the model is statistically significant, and the relationship between the independent variable and the dependent variable is more significant.

TABLE IX. COEFFICIENT SA

\begin{tabular}{|c|c|c|c|c|c|c|c|c|}
\hline & \multirow[b]{2}{*}{ Model } & \multicolumn{2}{|c|}{$\begin{array}{c}\text { Unstandardized } \\
\text { Coefficients }\end{array}$} & \multirow{2}{*}{$\begin{array}{c}\text { Standardized } \\
\text { Coefficients } \\
\text { Beta } \\
\end{array}$} & \multirow[t]{2}{*}{$t$} & \multirow[t]{2}{*}{ Sig. } & \multicolumn{2}{|c|}{ Collinearity Statistics } \\
\hline & & $B$ & Std.Error & & & & Tolearance & $V I F$ \\
\hline \multirow[t]{3}{*}{1} & Constant & & .00 & & 64.920 & .000 & & \\
\hline & $\mathrm{X}_{1}$ & & .00 & .272 & 5.211 & .000 & 1.000 & 1.000 \\
\hline & $\mathrm{X}_{4}$ & & .00 & .296 & 5.669 & .000 & 1.000 & 1.000 \\
\hline
\end{tabular}

It can be concluded from Table IX that the significant value of factor 1 (profitability $\mathrm{X}_{1}$ ) and factor 4 (firm size $\mathrm{X}_{4}$ ) is 0.000 (less than 0.005), indicating that it is significantly related to asset-liability ratio. Its tolerance and expansion factor are 1, did not appear a big result, indicating that the two explanatory variables in the equation did not appear collinearity. And the constant quantity is 0.582 , the coefficient of $X_{1}$ is 0.047 , the coefficient of $\mathrm{X}_{4}$ is 0.051 , so the regression equation of liability influencing factor is obtained:

$$
\mathrm{Y}=0.582+0.047 \mathrm{X}_{1}+0.051 \mathrm{X}_{4}
$$

\section{RESEARCH CONCLUSIONS AND COUNTERMEASURES AND SUGGESTIONS}

\section{A. The Conclusions of the Study}

This paper analyzed the factors that affect the debt management of each company in the industry, and draw the following conclusions:

(1) Hypothesis1and hypothesis 4 set up, that is, the impact of corporate debt management factors are: profitability and business scale, and is positively related [6], The larger the size of the enterprise and stronger profitability, the size of its debt may be greater, of course, the greater the scale of the debt is that the greater its debt management capacity. Therefore, the new energy industry, each enterprise should pay great attention to the debt management strategy, reasonable arrangements for the financial structure, effectively avoid financial risks, and steadily enhance the value of enterprises.
(2) Hypothesis 2 and hypothesis 3 is not established, that China's new energy companies listed on the development capacity and operational capacity of its debt business has no significant impact. After repeated research, the results may be related to the industry or other factors, here is no longer indepth discussion.

\section{B. Countermeasures and Suggestions}

Enterprises in the use of debt financing strategy, we must fully understand that it is a double-edged sword, combined with their own factors, comprehensive and comprehensive analysis, reasonable use will bring greater benefits [7]. In view of the above conclusions, the following suggestions are put forward.

1) Rich financing methods, broaden the financing channels

First of all, because of the bond financing has a fast financing, low cost of capital, good borrowing flexibility and other advantages of enterprises can strive to expand the scale of bond financing, bond financing to become the main means of corporate debt financing is essential. Second, the commercial credit is also a way of financing, it is mainly in the process of commodity transactions gradually established to the business in the industry as a basis for credit, through deferred payments, business discounts, installments or advance payment of the formation of the enterprise Between the voluntary lending relationship, is a kind of natural financing, is the company's indirect credit behavior. This financing is more convenient, low cost, less restrictive conditions, its appropriate and flexible use, will be very conducive to the development of the company. 
2) Reasonable allocation of funds to optimize the capital structure

Enterprises should be stable and rapid development, we must rational use of financial leverage, good equity financing and debt financing a reasonable ratio, which is the basis for steady and healthy development of enterprises. If all aspects of a business are good, then it can consider the use of a higher debt ratio to seek better development [8]. On the contrary, its operating risk is higher, should be appropriate to reduce its debt ratio, optimize the capital structure, to ensure good business operation and development. Some companies are particularly important when they are limited by their size and weaker financial risk tolerance.

3) To strengthen the company's profitability, reduce the risk of debt service

Through debt financing operations, enterprises on the one hand to consider taking financial risks, on the other hand they need to consider taking business risks. Liabilities are required to be repaid on time, if the expected rate of return can not be achieved (or obtained), or even lower than the borrowing rate. At this point, companies will face is unable to repay the principal and interest on time, which may face a crisis of bankruptcy. Therefore, we should strengthen the company's profitability, to ensure that the principal interest can be repaid on time, reduce the risk of debt at the same time can benefit.

4) Make the appropriate estimate of the work, appropriate to adjust the scale of production

Before the use of funds, companies often need to consider the allocation of funds and income effects, the need for all aspects of the enterprise funds for the overall planning, according to the pre-planning of its funds allocated, and in the course of business according to the actual situation to adjust, In order to achieve the desired profit target [9]. On the contrary, in the adjustment of the scale, if only to see a broad market development space and blind expansion, did not fully consider its own can withstand the range, it is likely to lead to unreasonable capital structure, and even some money chain break, Affect the healthy development of enterprises.

\section{REFERENCES}

[1] Yu Lingli. Analysis and Suggestions on the Control of Asset-liability Ratio in Electric Power Construction Enterprises [J]. Contemporary Accounting, 2014 (11): 54-55.

[2] Zou Shu-liang, Wang Xiaoting, Liu Wenjun.Study on Driving Factors and Associated Effects of Diversification of Energy Enterprises in China - Taking China Guangdong Nuclear Power Group as an Example [J] .Chinese Journal of Energy, 2014 (02): 13-19.

[3] Huang Wenqun. Analysis of influencing factors of operating performance of listed companies in China [J]. Friends of Accounting, 2015, (09): 69-71

[4] Chen Lei. Enterprise debt management analysis [J]. Enterprise Herald, 2015 (14): 10-11.

[5] Zhao Jing. Debt management of the relevant issues [J]. Modern Economic Information, 2013 (21): 172-173.

[6] Qiu Daoxin. China's corporate debt management of the status quo and countermeasures analysis [J]. Development Research, 2013 (04): 125128.

[7] Xiao Lujia. Corporate debt management case financial thinking [J]. Finance and Accounting Research, 2013 (33): 218-219.

[8] Miao Xiufeng. On the corporate debt management of financial thinking [J]. China Chief Accountant, 2013 (09): 74-75.

[9] Li Kaifeng, Song Pengpeng, Wang Minmin. China's new energy industry listed companies operating performance research $[\mathrm{J}]$. Friends of Accounting, 2014, (15): 52-55. 